EPRA International Journal of Economic and Business Review-Peer Reviewed Journal Volume - 9, Issue -2, February 2021 | e-ISSN: 2347 - 9671| p- ISSN: 2349 - 0187

\title{
INFLUENCE OF FINANCIAL INSTABILITY AND ECONOMIC GROWTH IN FOREIGN DIRECT INVESTMENT IN SOUTH AFRICA
}

\begin{tabular}{|c|c|}
\hline $\begin{array}{c}\text { Badamasi Sani } \\
\text { Mohammed }\end{array}$ & $\begin{array}{c}{ }^{1} \text { Faculty Finance \& Administrative Sciences, } \\
\text { Department of Management, } \\
\text { Almadinah International University Malaysia } \\
\text { Mediu }\end{array}$ \\
\hline $\begin{array}{c}\text { Sadun Naser Yassin } \\
\text { Alheety }\end{array}$ & ${ }^{2}$ Faculty Finance \& Administrative Sciences, \\
Department of Management, \\
Almadinah International University Malaysia \\
Mediu
\end{tabular}

\section{ABSTRACT}

Article DOI URL: https://doi.org/10.36713/epra6329

The prime objective of this paper is to study the impact of financial instability (FI) and economic growth (RGDPP) on foreign direct investment (FDI) in South Africa from 1970 to 2016 using Autoregressive Distributive Lag (ARDL) approach. Evidence from bound test reveals that FI, RGDPP, and FDI are cointegrated in the long run. Moreover, the result shows that financial instability and economic growth are positively significant and negatively insignificant influencing the foreign direct investment respectively. The study suggests that government should necessarily develop financial system to let economic growth make a positive contribution to foreign direct investment.

KEYWORDS: financial Instability (FI); Economic growth (RGDPP); foreign direct Investment (FDI); Autoregressive Distributive Lag (ARDL)

\subsection{INTRODUCTION}

Foreign Direct Investment (FDI) recorded available since the foundation of the province of British Empire in South Africa at the beginning of the nineteenth century. Before the foundation of the settlement, the South African economy was centred on farming fares to Europe. South Africa is rich with minerals, and around the compelling abuse of those minerals required a substantial capital escalated operation which was made conceivable by coordinate speculation streams from Europe (Gelb \& Black, 2001). 
Furthermore, during the late 1980s and early 1990s, there was a political turmoil in South Africa, for example white men authority and blacklists which influenced outside exchange and speculation adversely. The measures utilized incorporated an intentional arms ban which was set up by the United Nation (UN) amid the year 1963, in the year 1977 it was affirmed required ,a year after 1977, the denial of advances from the Assembled States Fare Import Bank, an oil ban initially began by relationship of Oil Producing Exporting Countries(OPEC) in 1973 and strengthened in a comparative move by Iran in 1979, a 1983 prohibition on International Monetary Fund (IMF) advances, a 1985 endpoint of most foreign advances by private banks, the United States 1986 Far reaching Antiapartheid Act, which constrained exchange and demoralized Joined States speculators, and finally the 1986 European Economic Community (EEC) restriction on exchange and venture. The Organization African Unity (OAU) likewise disheartened exchange with South Africa, in spite of the fact that eyewitnesses anticipated that Africa's authoritatively unreported exchange with South Africa outperformed R10 billion every year in the late 1980s (United Nations, 1985).

In light of the normal advantages of FDI, many examinations have been led to look at the Effect of FDI on monetary development, yet just a couple of studies have considered the effect of FDI with regards to SubSaharan Africa (SSA). However, this paper fills the void in analyzing the Effect of Budgetary precariousness and monetary development on Outside Direct Interest in South Africa, and furthermore the paper adds to the writing on money related unsteadiness, and financial development are emphatically critical and adversely unimportant impacting the FDI separately, many writers have noticed that FDI has differential impacts and that it has been more profitable in a few locales than others (Agosin and Mayer, 2000; Kumar and Pradhan,2002; Sylwester, 2005). Kumar and Pradhan (2002) and Sylwester (2005), for instance, assert that FDI is less powerful in SSA than in Latin America due to it significance's in the territory. Therefore, the purpose of this study is to investigate the impact of financial instability and output growth on foreign direct investment in South Africa. The remaining sections of the paper organized as section two are the empirical literature; section three is the methodology, and empirical results and the final section is the conclusion and recommendations.

\subsection{LITERATURE REVIEW}

This study briefly reviews only recent past studies on the relationship between financial instability, economic growth, and foreign direct investment. The study start with the work of Anyanwu and Yameogo,
(2015) analysed, drivers of foreign direct investments (FDI) to West Africa using a panel data set from 19702010. They used OLS and GMM techniques for the estimations. Their results indicated that there is a $\mathrm{U}-$ shaped linkage between economic development and FDI inflows to West Africa. However, the quadratic element of real per capita GDP, trade openness, domestic investment, natural resources endowment, monetary integration, exports, and first year lag of FDI have significant positive influence on FDI inflows to West Africa; and there is a negative relationship between FDI inflows to the sub-region and loan factor of ODA, real GDP per capita, economic growth, domestic credit to the private sector and life expectancy. Anyanwu and Yameogo, (2015) examined the factors that drive foreign direct investments (FDI) by looking at regional heterogeneity among the five African regions. They employed a panel dataset from 1970 to 2010 of 53 African countries divided into Central, East, North, Southern, and West Africa. They used GMM and OLS techniques for the estimations. Their result indicated that agglomeration has a strong positive relationship with FDI inflows in all the regions except Central Africa. But, in West Africa, the second lag of FDI is significantly negative. Maitah, Hodrab, Tomsík, and Benesová, (2015) measured and analyzed the impact of Foreign Direct Investment (FDI), domestic investment and imports on economic growth in developing countries such as Palestine. They used time series data during the period 1995-2014. The Least square method has been adopted to assess these factors on total domestic production of Palestine and results showed that FDI has a negative influence on economic growth, in contrast to the effect of domestic investment and imports which was examined to be positive.

Turkson, Gyeke-Dako, and Amissah, (2015) also, used the bound co-integration test to study how Foreign Direct Investment (FDI) influenced Ghana's growth through the financial environment. They employed time series data covering the period 19772010. The results showed that both in the long run and the short run, FDI would have a better impact on growth in a large financial environment, and Ahmed, (2016) examined that, the long-run causes of FDI in oil-exporting countries and the causal link between FDI and economic growth in the group of countries. They applied to sample data comprises 44 oil-exporting countries over 30 years from 1984-2012. They concluded that FDI does not contribute to economic growth in oil-exporting countries; the only contribution is observed within non-rentier and non-Islamic oilexporting countries. Hossain, (2016) explored that, the relationship between foreign direct investment, economic freedom and economic growth using panel data for 79 developing countries from 1998 to 2014. He applied Pedroni residual co-integration test, feasible 
GLS (FGLS), generalized least square (GLS), pooled OLS, fixed effect, random effect, Poisson regression, praise-Winston, generalized method of movement (GMM) and generalized estimating equation (GEE) methods to estimates the linkage. The result of OLS and generalized method of movement showed that, the business trade freedom, size, investment freedom, property rights, freedom from corruption, labor freedom, financial freedom, fiscal freedom, monetary freedom have a significant positive impact on FDI.

Ojewumi and Akinlo, (2017) investigated that, the dynamic interactions among the inflow of foreign direct investment, environmental quality and economic growth of the countries in Sub-Saharan Africa (SSA). The dynamic interaction was examined through Panel Vector Error Correction (PVEC) and Panel-Vector Autoregressive (PVAR) methodologies on a sample of 33 SSA countries. The result of panel cointegration test showed that the long-run association among the variables. Paramati, Apergis, and Ummalla, (2017) empirically explored to what extent both foreign (FDI inflows) capital and domestic (stock market) affect clean energy uses across the G20, OECD, and EU covering the period 1993-2012. Their results of longrun elasticity document that both FDI and stock market developments play an important role in stimulating clean energy uses across all three-country groups. Tuman and Shirali, (2017) applied a cross-sectional time-series data set for 66 countries for the period of 2003-2010 investigate the impact of several political and economic variables on Chinese FDI in Africa and Latin America. They result found Chinese FDI is influenced by natural resources and trade flows in host economies, including ores and metals and oil resources, also being focused on markets with lower per capita income.

\section{METHODOLOGY AND EMPIRICAL RESULTS}

\subsection{Introduction}

This paper attempts to investigate the impact of investment in South African. Foreign direct investment is estimated using the natural logarithm of foreign direct investment inflow as a percentage of GDP. Furthermore, this study used three major financial indicators as a measure of financial instability. Output growth was estimated using the natural logarithm of the real gross domestic product per capita.

\subsection{Analytical Method}

This study used time series data over the period from 1970 to 2016 to observe the impact of financial stability, output growth on foreign direct investment in South Africa. Financial stability and output growth are the independent variables while foreign direct investment is the dependent variables. The data were source from World Bank Development Database, 2017. The general function of the model is given as:

$F D I=f(F S, E C$,

This study transformed all the variables into natural logarithms to capture their elasticity value and set them free from the problem of heteroscedasticity. The empirical version of the model is constructed as:

$$
\begin{aligned}
& L N F D I_{i t}= \\
& \gamma_{t}+\delta_{1 t} L N F S_{t}+\delta_{2} L N G D P_{t}+\mu_{t}
\end{aligned}
$$

Where $L N F D I_{i t}$, is the natural logarithm of foreign direct investment, $L N F S_{t}$ is the natural logarithms of financial stability, $L N G D P_{t}$ is the natural logarithms of output growth. $\mu_{t}$ is the random error term which is assumed to have a normal distribution with zero mean and predictable variance.

\subsection{Unit root test}

In time series analysis, before running the relationships between the variables unit root must be tested for stationarity. For this determination, in this present study, the conventional Phillips and Perron (1988) and the Augmented Dickey-Fuller (1979) were used. The following table presented the result of both test

financial stability, and output growth on foreign direct

\section{Table 1 Unit root test}

\begin{tabular}{ccccc}
\hline & \multicolumn{2}{c}{ ADF } & \multicolumn{2}{c}{ PP } \\
\hline Variables & Level & 1st Diff. & Level & 1st Diff. \\
& t stats & t stats & t stats & t stats \\
$F D I$ & $-4.9530^{*}$ & $-10.398^{*}$ & $-5.079^{*}$ & $-11.616^{*}$ \\
$F I$ & $-3.501^{* *}$ & $-9.113^{*}$ & $-3.404^{* * *}$ & $-9.097^{*}$ \\
RGDPP & -1.815 & $-5.928^{*}$ & -1.820 & $-5.922^{*}$ \\
\hline
\end{tabular}

Note: $* * *$ and $* * *$ Denotes rejection of the null hypothesis at $10 \%$ and $5 \%$ and $1 \%$ significance level

The above table 1 FDI and FI are found to be stationary at $1 \%, 5 \%$ at both level and first difference, while RGDPP was stationary at first difference at $1 \%$, levels of significance. Thus, the variables are stationary and integrated of the same order.

\subsection{Bound Test to Cointegration}

The bound test to cointegration method allowed for the integration of the variables regardless of their order and whether they are stationary at $\mathrm{I}(0)$ or $\mathrm{I}(1)$. Secondly, the ARDL determined a Dynamic 
Unrestricted Error Model (UECM) through a linear transformation. The UECM integrates the short-run dynamics with the long-run equilibrium without losing

$$
\begin{aligned}
\Delta L N F D I_{t}=\theta_{1} & +\sum_{i=0}^{n} \beta_{1} \Delta L N F D I_{t-i}+\sum_{i=1}^{n} \beta_{2} \Delta L N G D P_{t-i}+\sum_{i=0}^{n} \beta_{3} \Delta L N F I_{t-i}+\delta_{2} L N F A_{t-1}+\partial_{1} L N F D I_{t-1} \\
& +\partial_{2} L N G D P_{t-1}+\partial_{3} L N F I_{t-1}+\tau_{1 t}
\end{aligned}
$$

Where $\Delta$ is a first-difference operator, and $n$ is the optimal lag length. Analyzing the existence of the long-run and short run relationship amongst the variables in the above equations and is done using bounds testing procedure, which is the first stage in ARDL cointegration method and is based on the F-test statistic. Each equation combined both the long run and any information over time. The following are the model for the long run and short run coefficient. short run parameters. The Joint significance test, which implies no cointegration is given by the null hypothesis $H_{0}: \vartheta_{1}=\vartheta_{2}=\vartheta_{3}=\vartheta_{4}=\vartheta_{5}=\vartheta_{6}=0$. Therefore, rejecting the null hypothesis, i.e. $H_{1}: \vartheta_{1} \neq \vartheta_{2} \neq \vartheta_{3} \neq$ $\vartheta_{4} \neq \vartheta_{5} \neq \vartheta_{6} \neq 0$ suggested that cointegration exist amongst the variables.

Table 2 F-Bound Long run Estimates

\begin{tabular}{lll}
\hline Test Statistic & Value & $\mathrm{k}$ \\
\hline F-statistic & $7.287^{*}$ & 2 \\
\hline
\end{tabular}

Critical Value Bounds

$\begin{array}{lcc}\text { Significance } & \text { I0 Bound } & \text { I1 Bound } \\ 10 \% & 3.17 & 4.14 \\ 5 \% & 3.79 & 4.85 \\ 2.5 \% & 4.41 & 5.52 \\ 1 \% & 5.15 & 6.36\end{array}$

Note: *,* and ${ }^{* * *}$ Denotes rejection of the null hypothesis at $10 \%$ and $5 \%$ and $1 \%$ significance level

These results in Table 2 above suggested that cointegration exists between financial instability, output growth and foreign direct investment at $1 \%$ level of significance. This implied that financial instability, output and foreign direct investment have long run

Table 3 Short run and Long run Coefficients

\begin{tabular}{ccccc}
\hline Variable & \multicolumn{2}{c}{$\begin{array}{c}\text { Coefficient } \\
\text { Short run coefficients }\end{array}$} & $\begin{array}{c}\text { Std. Error } \\
\text { t-Statistic }\end{array}$ & Prob. \\
\hline$\Delta(F I)$ & 0.211 & 0.138415 & 1.529793 & 0.1341 \\
$\Delta(R G D P P)$ & -0.07 & 0.134732 & -0.541322 & 0.5914 \\
$E C M(-1)$ & $-0.77^{*}$ & 0.164627 & -4.659543 & 0.0000 \\
\hline \multicolumn{5}{c}{ Long Run Coefficients } \\
\hline Coefficient & Std. Error & t-Statistic & Prob. \\
\hline Variable & $0.27^{* * *}$ & 0.161639 & 1.707755 & 0.0956 \\
RGDPP & -0.09 & 0.178161 & -0.533669 & 0.5966 \\
\hline R ${ }^{2}$ & 0.31 & & \\
Setro & $1.396(0.259)$ & & \\
Normality & $0.274(0.762)$ & & \\
\hline
\end{tabular}

Note: ${ }^{*} * *$ and $* * *$ Denotes rejection of the null hypothesis at $10 \%$ and $5 \%$ and $1 \%$ significance level 
The result in Table 3 brackets and square brackets presented the t-statistics and p-values. In the short run, the coefficients for financial instability and output growth are positive and negatives respectively and statistically insignificant. While in the long-run, the coefficients for financial instability and output growth are significantly positive and in significantly negative respectively. Moreover, in theory, the ECM (1) must have a negative value and significant which is exactly the case in the present study. The higher the coefficient, the more stable the short-run association. The estimated coefficient of the ecm (-1) is -0.77 (at $1 \%$ significant) suggesting that in the absence of changes in the financial instability and output growth, deviation of the model from the long-run path is corrected by $77 \%$ per year, which is very fast. The implication is that it will take a little time to entirely return to long-run equilibrium if there is a shock to the financial instability and output growth. The long run relationship between financial instability and foreign direct investment is positive and statistically significant at $10 \%$. The indicated that $1 \%$ increase of financial instability would lead to increase of foreign direct investment by $0.27 \%$. The result also revealed that $1 \%$ increase of output growth would lead to the decline of foreign direct investment by $0.09 \%$. This result is in consistent with the studies of Tang, and Tan, (2014), Danakol, Estrin, Reynolds, and Weitzel, (2017), Goh, Sam, and McNown, (2017), Mohamed, Singh, and Liew, (2017). However, the results suggested that output does not stimulate foreign direct investment in the South African economy. The stability of the ARDL parameters is perceived by employing the CUSUM and CUSUMSQ tests established by Brown et al (1975). Figures 1 and 2 illustrated that the plot of the statistics from the CUSUM and CUSUMSQ is within the critical bounds at $5 \%$ significance level. This necessitates that all coefficients in the error correction model are stable over time. The particular models adopted in the study seem to be good sufficient and strong in assessing the long-run and short-run associations among financial instability, output growth and foreign direct investment in South Africa.

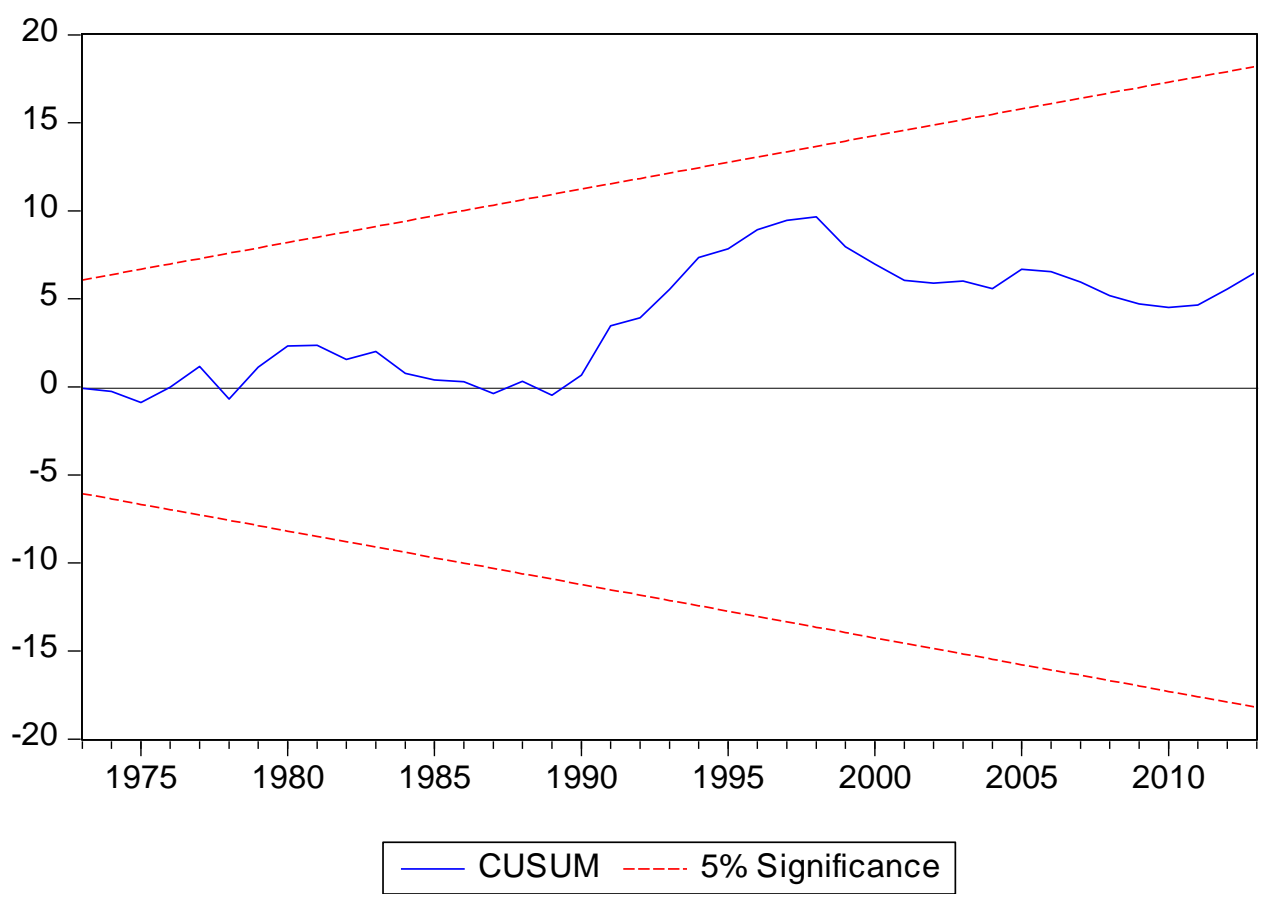

Figure 1 Cusum Test 


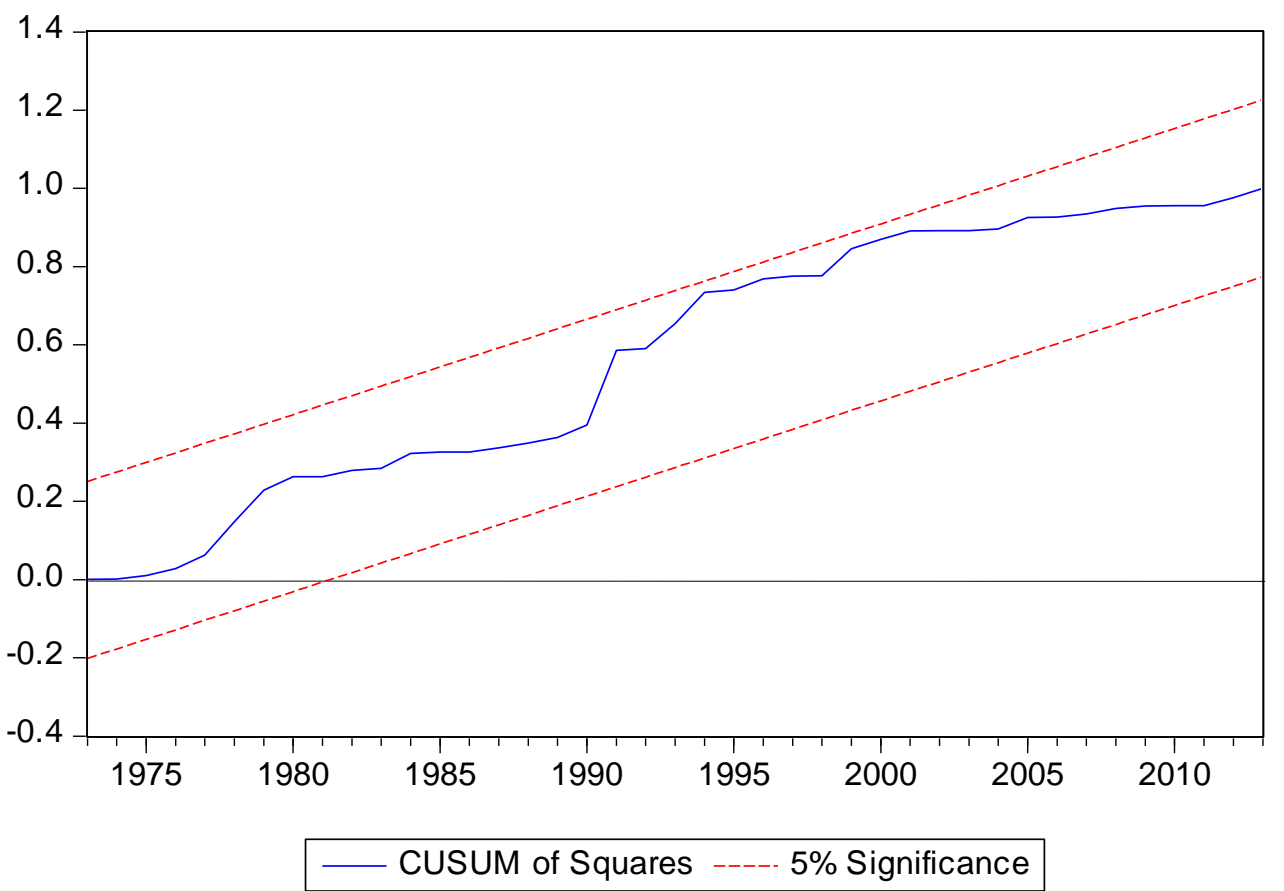

Figure 2 Cusum Test Square

\section{CONCLUSION}

This paper investigated the relationship between the series of financial instability, economic growth and foreign direct investment in South Africa for the period of 1970-2016. It applied an ARDL model to cointegration to examine the presence of a long-run relationship between the above-noted series. The topic evidences distinct responsiveness due to the promising relationship between the series with insinuations for financial instability. The results showed that there is cointegration between the variables specified in the model when FDI is the dependent variable. Financial instability stimulated foreign direct investment in South Africa in the long run. Despite the fact that there is an extensive certainty that economic growth can generate positive FDI for the host country, these empirical results fail to confirm this. Financial instability is the main driver of foreign direct investment in South Africa. These results can make significant implications and recommendations for policymakers in South Africa. They suggested that for economic growth to have the predicted positive influence on FDI, South Africa will have to commence severe reforms with strong goals and strong commitments. It has to recover its desirability of economic growth through a series of further motivated structural policies, improving its educational and financial system, and increasing its infrastructure.

\section{REFERENCES}

1. Adams, S. (2009). Foreign direct investment, domestic investment, and economic growth in SubSaharan Africa. Journal of Policy Modeling, 31(6), 939-949.

2. Ahmed, S., Ahmad, M., Swami, B. L., \& Ikram, S. (2016). A review on plants extract mediated synthesis of silver nanoparticles for antimicrobial applications: a green expertise. Journal of advanced research, 7(1), 17-28.

3. Anyanwu, J. C., \& Yameogo, N. D. (2015). What drives foreign direct investments into West Africa? An empirical investigation. African Development Review, 27(3), 199-215.

4. Belloumi, M. (2014). The relationship between trade, FDI and economic growth in Tunisia: An application of the autoregressive distributed lag model. Economic Systems, 38(2), 269-287.

5. Brown, R. L., Durbin, J., \& Evans, M. (1975). Techniques for testing the constancy of regression relations over time. Journal of the Royal Statistical Society, 37(2), 149-192. Retrieved from http://www.jstor.org/stable/2984889

6. Danakol, S. H., Estrin, S., Reynolds, P., \& Weitzel, $U$. (2017). Foreign direct investment via $M \& A$ and domestic entrepreneurship: blessing or curse?. Small Business Economics, 48(3), 599-612.

7. Dickey DA, Fuller WA. 1979. Distribution of the estimators for autoregressive time series with a unit root. Journal of the American Statistical Association 74: 427-431.

8. Duarte, L. D. R. V., Kedong, Y., \& Xuemei, L. (2017). The Relationship between FDI, Economic 
Growth and Financial Development in Cabo Verde. International Journal of Economics and Finance, 9(5), 132.

9. Duarte, L. D. R. V., Kedong, Y., \& Xuemei, L. (2017). The Relationship between FDI, Economic Growth and Financial Development in Cabo Verde. International Journal of Economics and Finance, 9(5), 132.

10. Faisal, F., Muhammad, P. M., \& Tursoy, T. (2017). Impact of Economic Growth, Foreign Direct Investment and Financial Development on Stock Prices in China: Empirical Evidence from Time Series Analysis. International Journal of Economics and Financial Issues, 7(1).

11. Gao, W., Emaminejad, S., Nyein, H. Y. Y., Challa, S., Chen, K., Peck, A., ... \& Lien, D. H. (2016). Fully integrated wearable sensor arrays for multiplexed in situ perspiration analysis. Nature, 529(7587), 509-514.

12. Goh, S. K., Sam, C. Y., \& McNown, R. (2017). Reexamining Foreign Direct Investment, Exports, and Economic Growth in Asian Economies Using a Bootstrap ARDL Test for Cointegration. Journal of Asian Economics.

13. Homer-Dixon, T. F. (1994). Environmental scarcities and violent conflict: evidence from cases. International security, 19(1), 5-40.

14. Marais, H. (2001). South Africa: Limits to change: The political economy of transition. Palgrave Macmillan.

15. Mohamed, M. R., Singh, K. S. J., \& Liew, C. Y. (2017). Impact of foreign direct investment \& domestic investment on economic growth of
Malaysia. Malaysian Journal of Economic Studies, 50(1), 21-35.

16. Ojewumi, S. J., \& Akinlo, A. E. (2017). Foreign direct investment, economic growth and environmental quality in sub-saharan Africa: a dynamic model analysis. African Journal of Economic Review, 5(1), 48-68.

17. Paramati, S. R., Apergis, N., \& Ummalla, M. (2017). Financing clean energy projects through domestic and foreign capital: The role of political cooperation among the EU, the G20 and OECD countries. Energy Economics, 61, 62-71.

18. Phillips, $P \&$ Perron, $P$ (1988). Testing for a unit root in time series regression. Biometrika, vol. 75 , no. 2, p. 335.

19. Sbia, R., Shahbaz, M., \& Hamdi, H. (2014). A contribution of foreign direct investment, clean energy, trade openness, carbon emissions and economic growth to energy demand in UAE. Economic Modelling, 36, 191-197.

20. Tang, C. F., \& Tan, B. W. (2014). The linkages among energy consumption, economic growth, relative price, foreign direct investment, and financial development in Malaysia. Quality \& Quantity, 1-17.

21. Tuman, J. P., \& Shirali, M. (2017). The political economy of Chinese foreign direct investment in developing areas. Foreign Policy Analysis, 13(1), 154-167.

22. Turkson, F. E., Gyeke-Dako, A., \& Amissah, E. B. (2015). Foreign Direct Investment Spillovers and the Ghanaian Local Financial Environment. Modern Economy, 6(10), 1078-108 